\title{
Muslim pasts and presents: Displacement and city- making in a Delhi neighbourhood
}

\author{
Saeed Ahmad \\ Centre for Modern Indian Studies, University of Göttingen, Göttingen, Germany \\ Email: saeed.ahmad@uni-goettingen.de
}

(Received 29 October 2020; revised 18 August 2021; accepted 20 August 2021)

\begin{abstract}
Through an engagement with the histories of Muslim pasts, presences, and absences in the locality of Jangpura-Bhogal in the Indian capital city of Delhi, this article examines the constitutive relationship between displacements and city-making. It addresses Jangpura-Bhogal's post-colonial history (1947-present) through instances of the erasure of Muslim property, spaces, and histories, and the reoccupations, replacements, and redefinition of spaces, properties, and memories that they constituted. The article shows how protracted material displacements of Muslim property and spaces have contributed to the erasure of a Muslim historical presence from Jangpura-Bhogal. By tracing the afterlives of these material displacements, it tracks how narrative discourses draw on these Muslim absences and the sense of an abstract 'diverse space' to produce new sets of exclusions and practices of Othering in the present. The discussion focuses on the processual/everyday, 'below the radar', and, at times, invisible displacements, more than sudden eruptions of violence or overt ideological projects aimed at a deliberate Muslim erasure. Thus, Delhi's post-colonial history is not only about the well-rehearsed story of migrations and arrivals but equally about departures and displacements that have produced the neighbourhood and the city as particular kinds of majoritarian places and spaces. Current acts of Muslim displacement, that is, the Delhi 'riots' of February 2020 are enabled not only through visible and violent histories of Muslim marginalization, but also by longer histories of non-overt erasures, displacements, and replacements.
\end{abstract}

Keywords: Delhi; urban; displacement; Muslim; memory

\section{Introduction}

Through an engagement with the histories of Muslim pasts, presences, and absences in the locality of Jangpura-Bhogal in the Indian capital city of

(C) The Author(s), 2022. Published by Cambridge University Press. This is an Open Access article, distributed under the terms of the Creative Commons Attribution licence (http://creativecommons.org/licenses/by/4.0/), which permits unrestricted re-use, distribution and reproduction, provided the original article is properly cited. 
Delhi, this article examines the constitutive relationship between displacements and city-making. Delhi's post-colonial history, we will see, is not only about the well-rehearsed story of migrations and arrivals but equally about departures and displacements, that is, processes, acts, and events of erasures and replacements that have produced the neighbourhood and the city as particular kinds of majoritarian places and spaces. In what follows I track modes of material displacement and their narrative afterlives that have structured the Jangpura-Bhogal locality over time (1947-present), through instances of the erasure of Muslim property, spaces, and histories, and the reoccupations, replacements, and redefinition of spaces, properties, and memories that they constituted. These instances illustrate how Delhi's post-colonial history has been marked by a long-term, ongoing, and socially sanctioned process of Muslim displacement.

Caught up in the normal rhythms of the urban everyday, these processes of ongoing, unapparent, 'below the radar'-at times invisible-displacements, more than sudden eruptions of violence or overt ideological projects aiming at a deliberate Muslim erasure, have reconstituted the urban fabric of Jangpura-Bhogal. Current-day Hindu-majoritarian projects of Muslim displacement that the city has witnessed in recent times, for instance, the overt abrogation of Muslim citizenship and rights through propaganda, legislative procedures, and outright violence ${ }^{1}$ unfold against this enabling backdrop of long-term, ongoing displacement.

I draw attention to 'constitutive and processual/everyday displacements' to join a growing body of literature on urban South Asia that takes a specific, delimited neighbourhood or the 'local' as an object of analysis to reflect on larger urban, national, and global processes. ${ }^{2}$ In a recent study, Diya Mehra aptly draws attention to the methodological challenges of undertaking neighbourhood histories of post-colonial urban India. A scarce and fragmentary archive, ${ }^{3}$

\footnotetext{
${ }^{1}$ Examples of such projects are the Proposed National Register of Citizens, the Citizenship Amendment Act of 2019, and the Delhi riots of February 2020. See 'The Citizenship (Amendment) Act, 2019', in The Gazette of India, Extraordinary (12 December 2019), http://egazette.nic.in/WriteReadData/2019/214646.pdf, [accessed 25 November 2021]; Delhi Minorities Commission, Report of the Fact-Finding Committee on the North-East Delhi Riots of February 2020 (New Delhi: Delhi Minorities Commission, 2020), https://ia601906.us.archive.org/11/items/dmc-delhiriot-fact-report-2020/-Delhi-riots-Fact-Finding-2020.pdf, [accessed 31 December 2021].

${ }^{2}$ Jim Masselos, 'Power in the Bombay "Mohalla", 1904-15: An Initial Exploration into the World of the Indian Urban Muslim', in The City in Action: Bombay Struggles for Power (New Delhi: Oxford University Press, 2007), pp. 15-45; Stephen Legg, 'A Pre-Partitioned City? Anti-Colonial and Communal Mohallas in Inter-War Delhi', South Asia: Journal of South Asian Studies 42, no. 1 (2019), pp. 170-187, https://doi.org/10.1080/00856401.2019.1554472; Geert de Neve and Henrike Donner (eds), The Meaning of the Local: Politics of Place in Urban India (New York: UCL Press, 2006); Nida Kirmani, Questioning the Muslim Woman: Space, Identity and Insecurity in an Urban Locality (New Delhi: Routledge, 2013); Laurent Gayer and Christophe Jaffrelot (eds), Muslims in Indian Cities: Trajectories of Marginalisation (London: Hurst, 2012); Diya Mehra, 'Jangpura Triptych: Striated Settlements, Neighbourhood Activism, and Delhi's Residential Mobility', Economic and Political Weekly 55, no. 51 (2020), pp. 57-67.

${ }^{3}$ Compared to the colonial archive, many post-colonial documents are either in the process of being catalogued or are spread out across various governmental institutions that aggressively guard their record rooms from the prying eyes of young researchers without jugaad (connections).
} 
the dense social complexity of spaces like Jangpura-Bhogal, dominant and exclusionary narratives, and the relatively easier recall of critical events and transformations limit attempts at 'whole' and everyday histories. ${ }^{4}$ However, the very silences, erasures, and Otherings produced by the limits of the archive, memory, and the field ${ }^{5}$ are a crucial resource to understand the production of neighbourhoods and cities. Thus, this article departs from, yet complements Mehra's analysis of space-making by addressing neighbourhood formation through its accretive dispossessions and erasures. It argues that the processes and strategies related to present and arrival populations are accompanied by past material displacements, transformations, and dispossessions, and present everyday narrative, symbolic exclusions, and erasures that produce the neighbourhood, its histories, and populations.

Fine-grained empirical accounts of place-making, migration, and displacement in urban space, while drawing implicit connections between displacement and city-making, ${ }^{6}$ mostly focus on deliberate event-driven procedures through the lens of urban planning and gentrification. ${ }^{7}$ Moreover, the focus remains either on 'arrival populations' ${ }^{8}$ or displaced, yet present,

\footnotetext{
${ }^{4}$ Mehra, 'Jangpura Triptych'.

${ }^{5}$ A greater discussion on the nature, silences, and erasures of the archive and memory are beyond the scope of this article. See Carlo Ginzburg, Threads and Traces: True, False, Fictive (Berkeley: University of California Press, 2012); Ann Laura Stoler, Along the Archival Grain: Epistemic Anxieties and Colonial Common Sense (Princeton: Princeton University Press, 2008); Gyanendra Pandey, 'The Evidence of the Historian', in Remembering Partition: Violence, Nationalism and History in India (Cambridge: Cambridge University Press, 2001), pp. 67-91; Paul Connerton, How Societies Remember (Cambridge: Cambridge University Press, 1989); Paul Ricœur, Memory, History, Forgetting (Chicago: University of Chicago Press, 2004); Shahid Amin, Event, Metaphor, Memory: Chauri Chaura, 1922-1992 (Berkeley and Los Angeles: University of California Press, 1995); Stephen Legg, 'Violent Memories: South Asian Spaces of Postcolonial Anamnesis', in Cultural Memories, (eds) P. Meusburger, M. Hefferman and E. Wunder (Dordrecht: Springer, 2011), pp. 287-303; Doreen Massey, 'Places and Their Pasts', History Workshop Journal 39, no. 1 (1995), pp. 182-92, https://doi.org/10.1093/hwj/39.1.182; James A. Tyner, Landscape, Memory, and Post-Violence in Cambodia (London: Rowman and Littlefield International Ltd, 2017).

${ }^{6}$ Gautam Bhan, In the Public's Interest: Evictions, Citizenship, and Inequality in Contemporary Delhi (Athens: University of Georgia Press, 2016); Amita Baviskar, Uncivil City: Ecology, Equity and the Commons in Delhi (New Delhi: SAGE Yoda Press, 2020); Emma Tarlo, Unsettling Memories: Narratives of the Emergency in Delhi (London: C. Hurst, 2003).

${ }^{7}$ Rowland Atkinson, 'Losing One's Place: Narratives of Neighbourhood Change, Market Injustice and Symbolic Displacement', Housing, Theory and Society 32, no. 4 (2015), pp. 373-388, https://doi. org/10.1080/14036096.2015.1053980; Fang Xu, "'Pudong Is Not My Shanghai": Displacement, Place-Identity, and Right to the "City" in Urban China', City and Community 19, no. 2 (2020), pp. 330-351, https://doi.org/10.1111/cico.12491. One of the notable exceptions is Corbridge and Simpson's study which highlights the crucial linkages between majoritarian ideology, practices of place-making, and spatial transformations. Stuart Corbridge and Edward Simpson, 'Militant Cartographies and Traumatic Space: Ayodhya, Bhuj and the Contested Geographies of Hindutva', in Colonial and Postcolonial Geographies of India, (eds) Saraswati Raju, M. Satish Kumar and Stuart Corbridge (London: Sage, 2006), pp. 70-84.

${ }^{8}$ Talja Blokland, 'Celebrating Local Histories and Defining Neighbourhood Communities: PlaceMaking in a Gentrified Neighbourhood', Urban Studies 46, no. 8 (2009), pp. 1593-1610, https://doi. org/10.1177/0042098009105499; Kristen Sarah Biehl, 'A Dwelling Lens: Migration, Diversity and Boundary-Making in an Istanbul Neighbourhood', Ethnic and Racial Studies 43, no. 12 (2019),
} 
populations. ${ }^{9}$ This article argues for the foundational role of displacements (both material and symbolic) in urban pasts and presents by addressing both arrivals/presence and departures/absence.

The rich studies on post-colonial and contemporary India address Muslim marginalization through the lens of ghettoization either in the immediate aftermath of the Indian partition, ${ }^{10}$ post-1980s processes of ascendant Hindu nationalism and neoliberal transformations, ${ }^{11}$ or through the post-colonial state's overt attempts at forgetting urban histories and memories. ${ }^{12}$ While drawing attention to longer and more subtle everyday histories of marginalization, the focus remains on planned political, social, and economic projects; Muslim majority neighbourhoods; and known historical spaces and monuments associated with the Muslim presence in the city (for example, mosques and monuments built by various Muslim elites and rulers in Delhi). While acknowledging the role of such ideological events and procedures, this article addresses the understudied, hidden, non-overt processes of othering outside of Muslim neighbourhoods and 'big' historical monuments.

Drawing on studies that link memories, displacements, and the production of neighbourhoods and cities, ${ }^{13}$ the article rethinks displacements by

pp. 2236-2254, https://doi.org/10.1080/01419870.2019.1668035; Aditi Mukherjee, 'Re-thinking Protracted Displacements: Insights from a Namasudra Refugee Camp-Site in Suburban Calcutta', Contemporary South Asia 28, no. 1 (2020), pp. 58-73, https://doi.org/10.1080/09584935.2019.1666089.

${ }^{9}$ Annika Lems, 'Placing Displacement: Place-Making in a World of Movement', Ethnos 81, no. 2 (2014), pp. 315-337, https://doi.org/10.1080/00141844.2014.931328; Tarlo, Unsettling Memories; Atkinson, 'Losing One's Place'; Xu, “Pudong Is Not My Shanghai”; Mukherjee, 'Re-thinking Protracted Displacements'.

${ }^{10}$ Vazira F.Y. Zamindar, 'Muslim Exodus from Delhi', in The Long Partition and the Making of Modern South Asia: Refugees, Boundaries, Histories (New York: Columbia University Press, 2007), pp. 19-44; Rotem Geva, 'The Scramble for Houses: Violence, a Factionalized State, and Informal Economy in Post-Partition Delhi', Modern Asian Studies 51, no. 3 (2017), pp. 769-824, https://doi. org/10.1017/S0026749X1600010X.

${ }^{11}$ Gayer and Jaffrelot, Muslims in Indian Cities; Kirmani, Questioning the Muslim Woman; Ghazala Jamil, Accumulation by Segregation: Muslim Localities in Delhi (New Delhi: Oxford University Press, 2017); Renu Desai, "Producing and Contesting the "Communalized City": Hindutva Politics and Urban Space in Ahmedabad', in The Fundamentalist City? Religiosity and the Remaking of Urban Space, (eds) Nezar AlSayyad and Mejgan Massoumi (Abingdon: Routledge, 2011), pp. 99-124; Parvis Ghassem-Fachandi, Pogrom in Gujarat: Hindu Nationalism and Anti-Muslim Violence in India (Princeton: Princeton University Press, 2012).

${ }^{12}$ Anand Vivek Taneja, Jinnealogy: Time, Islam, and Ecological Thought in the Medieval Ruins of Delhi (Stanford: Stanford University Press, 2018); Mrinalini Rajagopalan, 'Postsecular Urbanisms: Situating Delhi within the Rhetorical Landscape of Hindutva', in The Fundamentalist City?, (eds) Nezar and Massoumi, pp. 257-282; Legg, 'Violent Memories'.

${ }^{13}$ Amy Mills, 'Boundaries of the Nation in the Space of the Urban: Landscape and Social Memory in Istanbul', Cultural Geographies 13 (2006), pp. 367-394; Taneja, Jinnealogy; Anna Wylegała, 'The Absent "Others": A Comparative Study of Memories of Displacement in Poland and Ukraine', Memory Studies 8, no. 4 (2015), pp. 470-486, https://doi.org/10.1177/1750698015575175; Krysta Ryzewski, "No Home for the "Ordinary Gamut": A Historical Archaeology of Community Displacement and the Creation of Detroit, City Beautiful', Journal of Social Archaeology 15, no. 3 (October 2015), pp. 408-431, https://doi.org/10.1177/1469605315601907; Tarlo, Unsettling Memories; Legg, 'Violent Memories'; Tyner, Landscape, Memory, and Post-Violence; Massey, 'Places and Their Pasts'. 
documenting the historical and everyday processes of othering shaped by different structural transformation and varying constellations of actors and interests. While acknowledging the role of planned or ideologically driven events and practices in this history, the discussion focuses on the obscure histories of Muslim displacements and addresses both the arrivals and the departures that have affected the iterative processes of neighbourhood and city-making. Thus, the main object of study is a 'mainstream' non-Muslim majority neighbourhood with a past and present of Muslim inhabitation.

Jangpura-Bhogal is a majority Sikh and Hindu neighbourhood area with small groups of Christians, Buddhists, Ravidasis, Jains, Kashmiri Muslims, and an extensive Afghan Muslim presence. Asserting a historical and contemporary brotherhood (bhaichara), residents often define Jangpura-Bhogal as a convivial space, citing these diverse presences, rich histories of arrivals, and the material landscape of different religious sites: a church, mosque, Buddhist temple, four gurudwaras (Sikh temples), a variety of temples (see Figure 2). The attempt is to document the historical and everyday processes of othering that constitute such perceived spaces of conviviality.

I develop my arguments in the following way. After a brief introduction to the specific setting of Jangpura-Bhogal, in the first section I examine the theme of 'material dispossessions' of Muslim property and space. Through a discussion of three cases from different historical moments, I develop an account of displacement as an ongoing process and draw attention to the range of actors and institutions involved. The second section focuses on the theme of 'narrative displacements' and shows how past material displacements and disjointed articulations of a 'diverse' space foster everyday narrative erasures and othering. The article concludes by revisiting the main arguments in the context of the communal othering and violent displacements that have recently taken place in Delhi, for example, the recent Delhi 'riots' of 2020.

This article is based on fieldwork conducted between 2017 and 2020 and utilizes official state, newspaper, and court archives; oral histories; fieldwork interviews; and observations. Fieldwork was conducted through daily multihour visits to private homes and public, religious, and organizational spaces. Informants were approached in public spaces, and through snowball sampling with prominent local individuals and organizations. Interviews and conversations were conducted in person and via telephone in Hindi, Urdu, and English. All translations are by the author. Due to the sensitive nature of some conversations, names of individuals in certain sections have been withheld or anonymized.

\section{Introducing Jangpura-Bhogal}

Jangpura-Bhogal is the quintessential migrant neighbourhood area in southeast Delhi, India: a highly diverse settlement in terms of class, caste, and religion that has witnessed continuous and diverse flows of migrants from its founding in the 1920 s to the present moment of Afghan migrant 


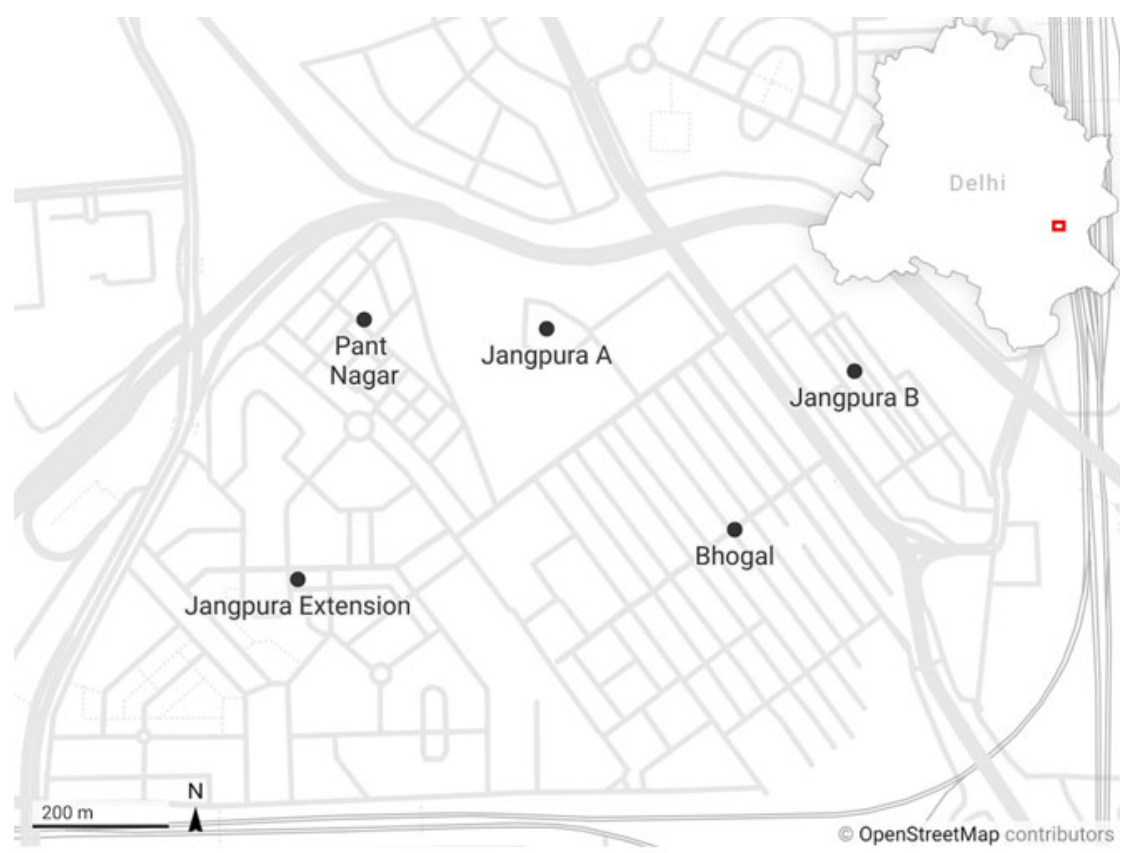

Created with Datawrapper

Figure I. Map of Jangpura-Bhogal and its location in Delhi. Source: @ OpenStreetMap Contributors, https:/www.openstreetmap.org/copyright. (Note: The map is not an accurate representation and is for illustrative purposes only.)

settlements. It is primarily a middle-class area with dispersed slum populations, comprising the contiguous localities of Bhogal, Jangpura-A, Jangpura Extension, Pant Nagar, and Jangpura-B, with a main urban street, Mathura Road, bifurcating the settlement (see Figure 1). The Barapulla nala (drain) separates it from the Muslim-majority neighbourhoods of Nizamuddin Basti and Nizamuddin West. Forming a part of the South East Delhi administrative division, Jangpura-Bhogal is included in the Delhi Legislative Assembly constituencies of Jangpura and Kasturba Nagar. ${ }^{14}$

The origins of the neighbourhood lie in the large-scale land acquisition process that followed the transfer of the British imperial capital from Calcutta to Delhi in 1911. This culminated in the displacement and relocation of numerous

\footnotetext{
${ }^{14}$ Geospatial Delhi Limited, ED-South East Assembly Constituency 41: Jangpura, 1:13000 scale, Government of Delhi, 2015, http://ceodelhi.gov.in/ACMAP/41.pdf, [accessed 29 November 2021]; Geospatial Delhi Limited, ED-South East Assembly Constituency 42: Kasturba Nagar, 1:6000 scale, Government of Delhi, 2015, http://ceodelhi.gov.in/ACMAP/42.pdf, [accessed 29 November 2021]. I use the hyphenated term 'Jangpura-Bhogal' to distinguish the specific locality of my research from the much larger spatial expanse of the electoral constituencies, which exist as political-administrative categories more than as 'lived neighbourhoods'.
} 


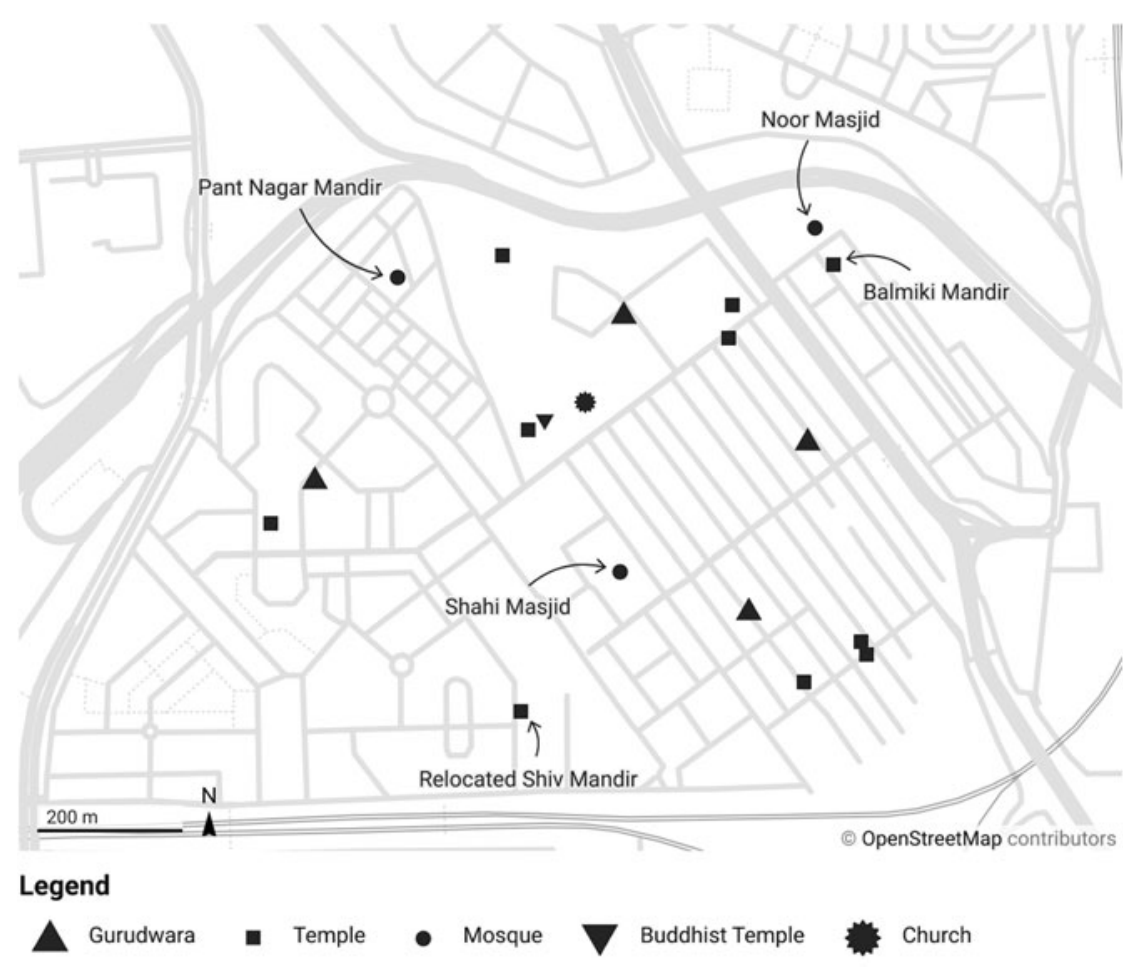

Created with Datawrapper

Figure 2. Map of religious spaces in Jangpura-Bhogal with names of relevant sites. Source: (c) OpenStreetMap Contributors, https://www.openstreetmap.org/copyright. (Note: The map is not an accurate representation and is for illustrative purposes only.)

villages from the proposed area for the new capital and the city's expansion. ${ }^{15}$ By 1922, inhabitants of the villages of Alipur Pilanji, Aliganj, Jor Bagh, Khairpur, ${ }^{16}$ Kushak, Garhi, the Safdarjung tomb complex, and Arab ki Sarai were relocated to the new planned 'model' village of Jangpura, carved out of the Nizampur village estate. ${ }^{17}$ This included populations from a diverse mix of lower and upper caste populations (the majority being Jatavs), Muslims,

\footnotetext{
${ }^{15}$ For a broader discussion on the making of New Delhi, see Robert Grant Irving, Indian Summer: Lutyens, Baker, and Imperial Delhi (New Haven: Yale University Press, 1984); Narayani Gupta, Delhi between Two Empires, 1803-1931: Society, Government and Urban Growth (Delhi: Oxford University Press, 1998); David A. Johnson, New Delhi: The Last Imperial City. Britain and the World (New York: Palgrave Macmillan, 2015); Swapna Liddle, Connaught Place and the Making of New Delhi (New Delhi: Speaking Tiger, 2018).

${ }^{16}$ The inhabitants of these villages were largely split between the larger Kotla Mubarakpur and Jangpura.

${ }^{17}$ For a history of 'model' towns, villages, and colonies, see William Glover 'A Colonial Spatial Imagination: British Knowledge of the City and Its Environs', in Making Lahore Modern:
} 
Christians, and Jains, who were settled along caste and community lines in a distinct grid pattern. ${ }^{18}$

Following this originary act of relocation which founded the locality, the next big displacement event witnessed in Jangpura-Bhogal was in 1947 in the aftermath of the partition and independence of India, when many Muslim inhabitants left for Muslim-majority areas like nearby Nizamuddin or else to Pakistan. This was, once again, a moment of considerable urban transformation-there was a 90 per cent increase in Delhi's population between 1941 and 1951. With the departure of Muslims and the influx of Hindu and Sikh refugees into the city, the area around Jangpura was acquired to construct Jangpura-A, Jangpura-B, Jangpura Extension, and Pant Nagar. ${ }^{19}$ The allocation of more than 1,200 properties to Hindu and Sikh partition refugees in the area, ${ }^{20}$ as in other parts of the city, was based on region, caste and class, ${ }^{21}$ with refugees coming in from West Punjab, the North West Frontier Provinces, Kashmir, and Sindh, including the regions of Rawalpindi, Peshawar, Multan, and Lahore, among others. ${ }^{22}$

Jangpura-Bhogal underwent another significant demographic and spatial transformation in the 1980s. As the Kashmir insurgency raged in northern India in the late $1980 \mathrm{~s},{ }^{23}$ Kashmiri Muslims, who had a long presence in the neighbourhood as itinerant salespeople engaged in the Kashmiri shawl trade

Constructing and Imagining a Colonial City (Minneapolis: University of Minnesota Press, 2008), pp. 27-58.

${ }^{18}$ Delhi State Archives (henceforth DSA), Chief Commissioner (henceforth CC), Home, 1914, file no. 2; DSA, CC, Home, 1914, file no. 18; DSA, Deputy Commissioner (henceforth DC), 1924, file no. 70; DSA, DC, 1927, file no. 42; First, Second Final Report of the Delhi Town Planning Committee Regarding the Selected Site. (London: His Majesty's Stationery office, 1913). With the foundation file untraceable, Jangpura's origin story is based on a combination of oral histories, private archives, and traces found in the archives. See also Liddle, Connaught Place, p. 34; Ranjana Sengupta, Delhi Metropolitan: The Making of an Unlikely City (London: Penguin Books, 2008), p. 30; Mehra, 'Jangpura Triptych', p. 59.

${ }_{19}^{19}$ DSA, CC, Local Self Government (henceforth LSG), 1955, file no. 1(158); DSA, CC, LSG, 1951, file no. 1(112); DSA, CC, LSG, 1951, file no. 1(103).

${ }^{20}$ Dhairya Maheshwari, 'Exclusive: More than 42,000 Pakistan Refugees Allotted Homes in Delhi at the Time of Partition, Reveals RTI', India TV, 5 March 2020, https://www.indiatvnews.com/news/ india/exclusive-more-than-42-000-pakistan-refugees-allotted-homes-in-delhi-at-the-time-of-partition-reveals-rti-595542, [accessed 29 November 2021].

${ }^{21}$ For a broader discussion on the nature of refugee allotments, see Ravinder Kaur, 'Governmental Policies and Practices of Resettlement', in Since 1947: Partition Narratives among the Punjabi Migrants of Delhi (New Delhi: Oxford University Press, 2007), pp. 84-120.

${ }^{22}$ Urvashi Butalia, The Other Side of Silence: Voices from the Partition of India (New Delhi: Penguin Books, 1998); Pandey, 'Folding the National into the Local: Delhi 1947-1948', in Remembering Partition, pp. 121-151. The refugee allotments in Jangpura-Bhogal had an estimated population of 8,500 people in an area of 156 acres. A. Bopegamage, Delhi: A Study in Urban Sociology (Bombay: University of Bombay, 1957), p. 82. National Archives of India (henceforth NAI), Home Affairs, Rehabilitation, RDB-B-12-5-48, 1963.

${ }^{23}$ The Indian state's failed promises to ensure Kashmiri sovereignty, rigged elections, and mass discontent in the 1980s led to the breakout of a full-scale armed movement for an independent Kashmir in 1989. Violence by both state and non-state forces, and the resulting instability, led to the mass exodus of Kashmiri Pandits and the departure of Kashmiri Muslims from the region. See Deepti Sharma, 'The Kashmir Insurgency: Multiple Actors, Divergent Interests, Institutionalized 
during the winter months, started to settle down in the neighbourhood, no longer as itinerants but as residents. This was also the time when the neighbourhood witnessed the arrival of Afghan refugees in the aftermath of the Soviet-Afghan War of 1979, with their numbers drastically increasing following the rise of the Taliban in Afghanistan in the mid-1990s. ${ }^{24}$ While the influx of refugees has slowed down, Afghan students and medical tourists have joined these populations in recent years. ${ }^{25}$ Finally, although not dealt with in this article, the area also has dispersed Tamil- and Bengali-speaking slum populations living in Jangpura-B and Pant Nagar. All of these diverse arrivals and departures make Jangpura-Bhogal an appropriate site to explore the thesis of ongoing displacement as a constitutive process of city-making.

\section{Material displacements}

\section{Chand Khan's property}

Independence for India and Pakistan in August 1947 was accompanied by the partition of the subcontinent and large-scale communal violence. The months of August and September saw the arrival of thousands of traumatized Hindu and Sikh refugees into Delhi from West Punjab and the Northwest Frontier Provinces, bringing stories of rape, pillage, murder, and abductions from the other side of the border. These stories, news from the radio and newspapers, and rumours of Muslims planning attacks led to mass hysteria and multiple incidents of violence in a city that had an already tense social fabric dating to the early twentieth century. ${ }^{26}$ The riots during this period included attacks on Muslim neighbourhoods and homes, the desecration and occupation of

Conflict', in Ethnic Subnationalist Insurgencies in South Asia: Identities, Interests and Challenges to State Authority, (ed.) Jugdep S. Chima (Abingdon: Routledge, 2015), pp. 17-40.

${ }^{24}$ Interview with UNHCR, 1 November 2018. With no official refugee policy, India grants asylum based on various international treaties and agreements. For a greater discussion, see Anwesha Ghosh, Identity and Marginality in India: Settlement Experience of Afghan Migrants (Abingdon: Routledge, 2019); Shuvro Prosun Sarker, Refugee Law in India (Singapore: Springer, 2017), https:// doi.org/10.1007/978-981-10-4807-4; Sahil K. Warsi, 'Being and Belonging in Delhi: Afghan Individuals and Communities in a Global City', PhD thesis, SOAS University of London, 2015; Nithya Rajan, 'Afghans in Delhi: Remembering the Past, Rectifying the Future', The Indian Express, 14 March 2020, https://indianexpress.com/article/opinion/web-edits/afghans-in-delhi-citizenship-amendment-act-caa-6313896/, [accessed 29 November 2021].

${ }^{25}$ Bindu Shajan Perapaddan, 'Interpreters without Borders', The Hindu, 28 January 2019, https:// www.thehindu.com/news/cities/Delhi/interpreters-without-borders/article26106962.ece,

[accessed 29 November 2021]; 'Indian Hospitals Are Doing a Roaring Trade in Medical Tourists from Afghanistan', Time, 3 March 2014, https://time.com/11213/afghan-medical-tourism-india/, [accessed 29 November 2021]; Syed Zafar Mehdi, 'For Afghan Patients, All Routes Lead to Indian Hospitals', Scroll.in, 27 November 2014, https://scroll.in/article/690844/for-afghan-patients-allroutes-lead-to-indian-hospitals, [accessed 29 November 2021].

${ }^{26}$ Rotem G. Halperin, 'The City as a Space of Suspicion: Partition, Belonging and Citizenship in Delhi, 1940-1955', PhD thesis, Princeton University, 2014; Christophe Jaffrelot, 'The Hindu Nationalist Movement in Delhi: From "Locals" to Refugees-and Towards Peripheral Groups?', in Delhi: Urban Space and Human Destinies, (eds) Véronique Dupont, Emma Tarlo and Dennis Vidal (New Delhi: Manohar, 2000), pp. 181-204; Legg, 'A Pre-Partitioned City?'. 
Muslim monuments and places of worship, and numerous incidents of the abduction and rape of women. An estimated 25,000 Muslims were killed, while others sought refuge in 'evacuee' camps like Purana Qila, 'Muslim zones' like Nizamuddin or Ballimaran, or religious sites like the Jama Masjid. ${ }^{27}$ While there was no official data recorded on the number of Muslim departures, the 1941 and 1951 censuses revealed a decline of 205,470 Muslims in Delhi $\left(3,04,971\right.$ in 1941 to 99,501 in 1951).$^{28}$ In the course of a decade, the Muslim population of the city thus declined from over 33 per cent to a little over 5 per cent. At the same time, the vast influx of refugees, numbering 495,391 (greatly exceeding the departing Muslims), led to an almost 90 per cent increase in Delhi's population, that is, it went from 9,17,939 in 1941 to $1,744,072$ in $1951{ }^{29}$ Thus, Delhi became what Gyanendra Pandey has called a 'Partition city'. ${ }^{30}$

As in other parts of Delhi, Muslims in Bhogal were subject to violence, with only a few managing to escape unharmed. Residents inform me that while some took refuge in nearby Nizamuddin, others left for Pakistan. As was the case in many parts of Delhi at the time, newly arrived Hindu and Sikh refugees as well as resident locals soon started occupying empty houses and spaces left behind by Muslims, often driving out Muslims from non-Muslim majority neighbourhoods. ${ }^{31}$ The violent expulsions and illegal occupations prompted the extension of the office of the Custodian-General of Evacuee Property, under the East Punjab Evacuees (Administration of Property) Ordinance of 1947, to Delhi. Introduced as a measure by the Indian and Pakistani governments to control forceful dispossessions, the Custodian was to be the guardian of abandoned properties until the original owners returned. In many instances, the Custodian acquired properties that had been abandoned by Muslims who were still in the city. ${ }^{32}$

Chand Khan, a resident of Jangpura-Bhogal, was one such individual. After losing his brothers and nephews in the violence of 1947, he sought refuge in neighbouring Nizamuddin. Assuming his death or departure to Pakistan, the Custodian acquired Chand Khan's three properties in 1948 (plots 591, 592, and 594). Its mission as the temporary guardian of properties with the

\footnotetext{
${ }^{27}$ Geva, 'The Scramble for Houses'; Zamindar, 'Muslim Exodus from Delhi'; Pandey, 'Folding the National into the Local'; Nazima Parveen, 'Ideas of Homeland and Politics of Space: A Study of "Muslim Localities" of Delhi', PhD thesis, University of Wellington, 2016. Muslim zones emerged at sites where the state could guarantee protection to Muslims. For a map of the Muslim zones and spaces of refuge, see Parveen, 'Ideas of Homeland and Politics of Space', p. 124.

${ }^{28}$ Prabha Chopra, Delhi Gazetteer (New Delhi: Ministry of Information and Broadcasting, 1976), p. 130

${ }^{29}$ Ibid., p. 127.

${ }^{30}$ Pandey, 'Folding the National into the Local', p. 122.

${ }^{31}$ Ibid., p. 126; Anis Kidwai, In Freedom's Shade, (trans.) Ayesha Kidwai (New Delhi: Penguin Books India, 2011), p. 143; Mehra, 'Jangpura Triptych', p. 60; DSA, CC, Relief and Rehabilitation (henceforth RR), $17-11,1950$.

${ }^{32}$ Partition violence and the evacuee property legislation eventually led to a simultaneous proliferation and shrinking of Muslim zones. See Zamindar, 'Economies of Displacement', in the Long Partition, pp. 120-159; Parveen, 'Ideas of Homeland and Politics of Space', pp. 103-131; Geva, 'The Scramble for Houses'.
} 
intention of restoring them to original owners quickly changed. With the continuing refugee crisis and the immense shortage of housing that resulted, the Custodian now became a trader of properties, authorized to auction and allot abandoned and unclaimed properties to refugees. ${ }^{33}$ This change in legislation allowed the Custodian to rent plot 594 to three refugee brothers in 1948, having evicting a local who was occupying it. ${ }^{34}$

By 1954, Chand Khan, the only surviving member of his family and thus entitled to all three properties, had approached the Custodian for their restoration. A year later in 1955, these properties became part of the compensation pool for the Ministry of Relief and Rehabilitation. Chand Khan had to approach the Custodian again and had the veracity of his claims proved through its enquiry reports in 1962 and 1963. While the order for restitution of the properties to Chand Khan was eventually issued, officials delayed proceedings, which led to the sale of plot 591 by the Rehabilitation Ministry in 1965 and its resale in 1966, thereby introducing major complications. ${ }^{35}$

In 1966, the official order for the restoration of properties accompanied a letter by Chand Khan agreeing to receive rent as compensation for the properties. However, by 1972, this compensation arrangement was annulled, and the settlement commissioner ordered the eviction of the occupants. This new order was issued in response to an amendment that had recently been passed, striking down the possibility of calculating compensation for mistakenly acquired properties. ${ }^{36}$

The eviction decision was challenged in the Delhi High Court by the occupants of Plot 594 in 1972, who agreed to pay rent in lieu of their eviction. The court quashed the eviction order in 1982, arguing that the Evacuee Property Act and its amendments meant that an allotment by the settlement commissioner (part of the office of the Custodian) was equivalent to a lease, thereby negating the earlier issuance of eviction orders. Moreover, the court stated that the office of the Custodian had failed to officially declare the properties as non-evacuee properties. During this time, Chand Khan's attempts came to an abrupt end: he died in 1979, having received neither compensation nor restoration of his properties after 25 years of litigation. His attempts were continued

\footnotetext{
${ }^{33}$ Ibid; Kaur, 'Governmental Policies', pp. 96-99. The evolution of evacuee property legislation was partly retaliatory in nature resulting from negotiatory deadlocks and the minority situation in India and Pakistan.

${ }^{34}$ S. Balbir Singh and Ors. vs. Rajni Kant, Settlement Commissioner, 1983 (4) DRJ 287, India Kanoon (Delhi High Court (henceforth DHC), 1983), https://indiankanoon.org/doc/1844958/, [accessed 29 November 2021].

${ }^{35}$ Qayyum Khan vs. Dda and Ors, 126 DLT 418, India Kanoon (DHC, 2006), https://indiankanoon. org/doc/453982/, [accessed 29 November 2021]; Union Of India vs. Qayyum Khan and Others, LPA 375/2008, India Kanoon (DHC, 2008), https://indiankanoon.org/doc/1033407/, [accessed 29 November 2021].

${ }^{36}$ The court cited Lachhman Dass \& Others vs. Municipal Committee, Jalalabad \& Others, 1969 AIR 1126, 1969 SCR (3) 645, India Kanoon (Supreme Court of India, 1969), https://indiankanoon.org/ doc/451064/, [accessed 29 November 2021].
} 
by his son Qayyum Khan who until recently was still involved in litigation around his father's properties either with the state or his own family members. ${ }^{37}$

Chand Khan's prolonged dispossession involved a constellation of actors, playing out in the office of the Custodian, the courtroom, and the housing market. It began with an overt violent, communal act against his family by locals that led to the material dispossession of his property, formalized through the Custodian whose actions displaced another local occupant of the property and introduced newly arrived refugees into the chain of possession. The market emerging from the new property regime being formed at the time now entered the story, complicated the process of recovery, and, later, assisted by the court and a now evolved evacuee property legislation, finalized the dispossession and reuse of this Muslim property.

Although it was never designed as a regime to displace Muslims, this was the effective outcome. The process unfolded through bureaucratic ineptitude and delays, jurisdictional overlaps, shifts, and constraints, rather than a planned ideological attempt at dispossession. Contingent factors like the development of lessee rights and market forces together provided legal sanction to Chand Khan's protracted displacement, first from the neighbourhood and then from his property. ${ }^{38}$

\section{Transforming historical space: The tomb and the temple}

I turn now to a different dimension of material displacements by addressing the displacement of historical space through a process that sedimented over multiple decades in the latter half of the twentieth century. This process of displacement involved a series of everyday individual and institutional actions that erased memories and practices, and, eventually, the actual physical existence of the site itself.

Colonial and post-colonial cartographic representations show the presence of a Muslim tomb in what is now the Pant Nagar neighbourhood of Jangpura-Bhogal. ${ }^{39}$ Today, however, the tomb is absent. In its place is the famous Pant Nagar Hindu temple complex (see Figure 3). In 2017, while collecting oral histories of the neighbourhood, I am told that the site of the complex was initially a Muslim tomb that was converted into a temple, a story embedded in popular memory and narrated by numerous residents. As I am informed, the key actors involved were a refugee widow, a young priest, ordinary residents

\footnotetext{
${ }^{37}$ Qayyum Khan vs Dda; Union Of India v. Qayyum Khan; Mohd. Yusuf Khan vs Qayyum Khan, India Kanoon, (Delhi District Court, 2013), https://indiankanoon.org/doc/94250811/, [accessed 29 November 2021].

${ }^{38}$ Studies have highlighted the role of state actors in the facilitation of Muslim displacement. See Geva, 'The Scramble for Houses'. While I do not rule out the possibility of Chand Khan's dispossession arose out of prejudice, the archive does not suggest it.

${ }^{39}$ Pilar Maria Guerrieri, Maps of Delhi (New Delhi: Niyogi Books, 2017), pp. 236, 245, 249; First, Second and Final Reports of the Delhi Town Planning Committee (London: His Majesty's Stationery Office, 1913), pp. 58-65; Survey of India, 'Greater Delhi Parks, Open Spaces and Historical Monuments', Town Planning Organization, June 1956, http://rgplan.com/delhi/Ministry_of_ Health_Map/scan009.jpg, [accessed 29 November 2021].
} 


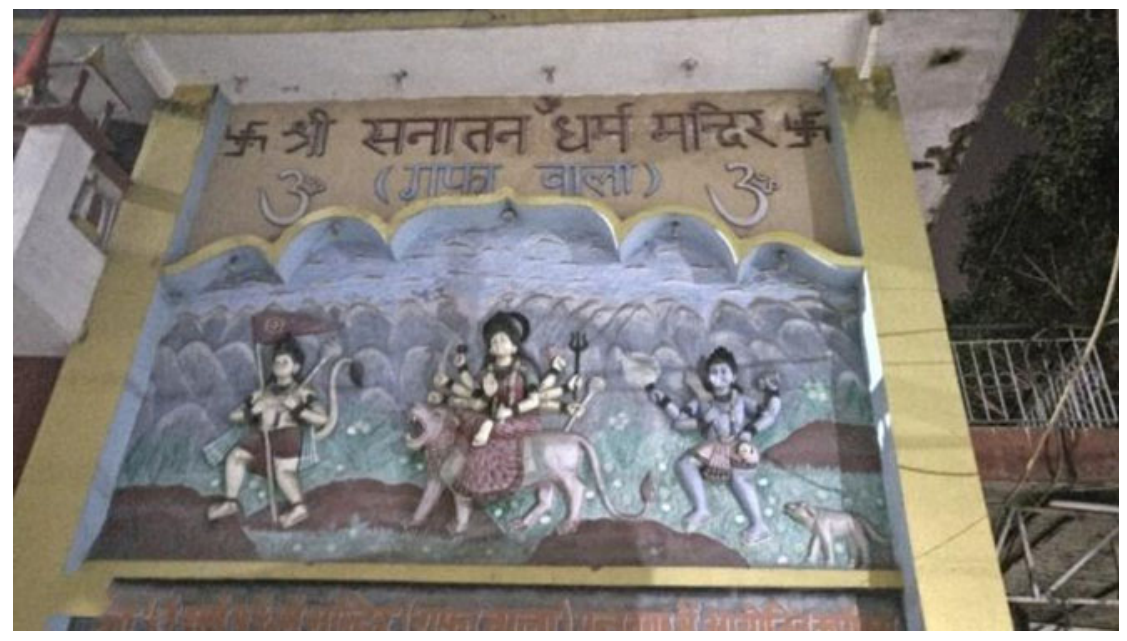

Figure 3. Entrance to the Temple Complex. Source: The author.

of neighbourhood, and well-connected figures like Goswami Girdhari Lal. ${ }^{40}$ My conversations with the widow's son, relatives, and other residents enrich the details of this story of how the newly arrived majority-Hindu residents of Pant Nagar in the 1950s encountered a large dilapidated Muslim tomb with an unmarked grave. An elderly homeless man sought shelter there and used coal to draw figures of the Hindu god Hanuman on one of the walls, dying soon after.

As the widow's son informs me, 'Now it cannot be that you have a temple and there is a grave in the middle. How can both things exist together? ${ }^{41}$ By the 1960s, the refugee widow living opposite the structure and a young priest from Rajasthan cleared the grave, purified the site (shuddikaran), and added stone-made statues of Hindu gods to establish a makeshift temple with regular kirtans (religious recitals) to attract a huge crowd, which also served as a source of income for both. The formal temple we see today was constructed by the Sanatan Dharam Sabha, a Hindu religious organization, with donations from residents. ${ }^{42}$

In the 1970s, Muslim residents from nearby Nizamuddin, along with the Delhi Wakf Board, laid claims to it as Wakf property. ${ }^{43}$ According to the

${ }^{40} \mathrm{He}$ was the head priest of the Laxminarayan Temple. Interview with family member, 4 February 2019.

${ }^{41}$ Interview with widow's son, 17 August 2017.

${ }^{42}$ Interview with residents of Jangpura-A, 5 March 2019.

${ }^{43}$ Under Islamic law, Wakfs are 'permanent dedications' of moveable or immoveable property for pious, religious, or charitable purposes. They can neither be sold nor transferred. The Wakf Act of 1954 and subsequent amendments make the Delhi Wakf Board the de facto guardian of all Muslim religious, spiritual, and historical spaces in Delhi. For a discussion on the Wakf Act of 1954 and its multiple amendments, see Hilal Ahmed, Muslim Political Discourse in Postcolonial India: Monuments, Memory, Contestation (New Delhi: Routledge India, 2015). See also Central Waqf 
widow's son, although the land did indeed belong to the Wakf, the Hindu nationalist Jan Sangh political party ruling the Municipal Corporation of Delhi (MCD) denied their claims. ${ }^{44}$ The remnants of the tomb, including the dome, were finally demolished in the late 1980s and a new structure, the Gufa Wala (cave) temple, was added to the complex. ${ }^{45}$ The Muslim tomb, now physically absent, exists in popular memory as a story of 'what once was'.

The story of the Muslim tomb that 'became' a Hindu temple can be contrasted with another instance from the neighbourhood-that of a makeshift Hindu Shiv temple within an old medieval structure in the Jangpura Extension area in 1952. Its purported illegality and interference with refugee housing construction projects underway at the time led to the temple's demolition by the local municipal authorities. This caused much dismay among residents and the mainstream print media who made public appeals and petitioned the government to provide adequate restitution for harming religious sentiments. Using evidence from the Archaeological Survey of India (ASI), residents asserted that the medieval structure within which the allegedly 'illegal' temple had been established was historically a Shiv temple. In a letter sent to the chief minister Brahm Perkash in May 1953, members of the Jangpura Temple Committee contrasted the 'big, deserted, dilapidated mosque' in the area (Shahi Masjid, the Bhogal mosque) that remained untouched by the state with a 'centuries old shrine' that had been ruthlessly destroyed, pointing out the blatantly differential treatment of religious structures by the state, and the meaningful differences between a 'dead space' like the deserted mosque and the 'alive space' of the Shiv temple filled with devotees. ${ }^{46}$ The vocal discontent of the residents, the negative media coverage, and the "historical proof provided by the ASI yielded results and led the government to allot another site for the Shiv temple towards the southern end of the neighbourhood. ${ }^{47}$ Hindu residents' attempts to construct a space of religious community

Council, Ministry of Minority Affairs, Government of India, http://centralwaqfcouncil.gov.in, [accessed 29 November 2021].

${ }^{44}$ Interview with widow's son, 17 August 2017. The Jan Sangh won the municipal elections in 1967 and 1971. See Jaffrelot, 'The Hindu Nationalist Movement in Delhi', p. 181. For an alternative retelling, see Mehra, 'Jangpura Triptych', p. 62.

${ }^{45}$ Personal communication, 29 January 2019. Reproduced from oral histories of residents, I suggest such prospective dates due to the near absence of an archive and details in the narratives. The temple authorities were granted land for a children's burial ground in 1972, suggesting that the temple was in place by then. See DDA, 'List of Properties for Department: Institutional', http:// 119.226.139.196/lands/INSTITUTIONAL.htm, [accessed 29 November 2021]. The claim to being a Wakf property would have probably emerged in the early 1970s when Delhi witnessed the emergence of a new Muslim political discourse around the heritage of a 'Royal Muslim past' through Delhi's Islamic monuments and ruins. Around this time, the Delhi Wakf Board released a number of gazette notifications for Wakf properties. See Ahmed, 'Jama Masjid and the Political Memory of a Royal Muslim Past', in Muslim Political Discourse, pp. 140-191.

${ }^{46}$ I borrow from Taneja's formulation of 'dead' and 'alive' spaces with respect to the monuments and ruins of the city. See Taneja, Jinnealogy.

${ }^{47}$ DSA, CC, RR, 1952, file no. 16-33, Jang Pura Temple Committee to Chief Minister, 20 May 1953. See also Mehra, 'Jangpura Triptych', p. 62. Organizations like the Mandir Raksha Committee involved in this agitation had a longer history of involvement in claims around religious sites in 
in Jangpura-Bhogal, while briefly interrupted, were nonetheless allowed to flourish.

The post-colonial bureaucratic regime built upon the legacies of the colonial state to categorize the ruins of Delhi as 'monuments' for symbolic recollections of the past. Others were turned into 'ruins', unprotected and of no historical or cultural interest to the state. ${ }^{48}$ The new populations now inhabiting spaces of the city, both victims and perpetrators of displacement, were disconnected from the histories and meanings of such ruins. ${ }^{49}$ Their transformation from refugees to citizens and residents required state-facilitated measures, and place-making in the neighbourhood through demands to improve the lived space or build religious spaces, ${ }^{50}$ some of which emerged through illegal occupations. $^{51}$

In the process, the newly arrived Hindu residents of Jangpura-Bhogal encountered pre-existing spaces with earlier histories of meaning and practice. 'Whoever comes to power will decide what will happen':52 this statement by a resident in the context of the Pant Nagar temple captures the difference in the trajectories of the temple and the tomb. One was the instance of a proclaimed historic Hindu temple, where a forgotten past was 'recovered' and articulated by a recently arrived population. Although it was demolished, its meanings and practices continued to prosper in a new space. The other was a Muslim tomb repurposed into a temple, its history and significance forgotten in the absence of the populations for whom the historical space had meaning. The interplay of presence and absence was also reflected in the differential access of communities to the state. Thus, while the temple demolition agitations prompted the state to grant new land for building the temple again in the neighbourhood, with a Hindu nationalist political party in power, Muslim claims to the space of the tomb were turned down by the municipal authorities.

Delhi, including an earlier Shiv temple dispute. See Anish Vanaik, 'Grave Investments: Property, Abstraction and Sacral Spaces', in Possessing the City: Property and Politics in Delhi, 1911-1947 (Oxford: Oxford University Press, 2020), pp. 192-220; Deepasri Baul, 'The Improbability of a Temple: Hindu Mobilization and Urban Space in the Delhi Shiv Mandir Agitation of 1938', Studies in History 36, no. 2 (2020), pp. 230-250, https://doi.org/10.1177/0257643020956624.

${ }^{48}$ Taneja, Jinnealogy; Ahmed, Muslim Political Discourse; Ravi Sundaram, Pirate Modernity: Delhi's Media Urbanism (London: Routledge, 2010). The process of converting 'ruins' into 'monuments' routinely encountered and contested with 'non-official' histories and claims to these spaces. See Deborah Sutton, 'Inhabited Pasts: Monuments, Authority, and People in Delhi, 1912-1970s', The Journal of Asian Studies 77, no. 4 (November 2018), pp. 1013-1035, https://doi.org/10.1017/ S0021911818000906; Mrinalini Rajagopalan, Building Histories: The Archival and Affective Lives of Five Monuments in Modern Delhi (Chicago: University of Chicago Press, 2016).

${ }^{49}$ Taneja, 'Stones, Snakes, and Saints: Remembering the Vanished Sacred Geographies of Delhi', in Jinnealogy, pp. 181-225.

${ }^{50}$ See, for example, Delhi Police Records, IIIrd Instalment, F. No. 68 and 69, Manuscript Division, Nehru Memorial Museum and Library; NAI, Works, Housing and Supply, Lands, L-3-163, 1962.

${ }^{51}$ This widespread phenomenon in the aftermath of the partition was documented by the Sunni Majlis-e-Awkaf (the Wakf Board's predecessor). DSA, CC, RR, 1954, file no. 32-2; DSA, DC, 1949, file no. 4. The Bhogal mosque was under occupation until 1953. See DSA, CC, RR, 1954, file no. 32-2.

${ }^{52}$ Bhogal resident, personal communication, 29 January 2019. 
Like the protracted process of dispossessing Chand Khan of his property, the erasure of Muslim historical space represented by the tomb's makeover as a Hindu temple was also a gradual and sedimented process. An occupation by a homeless man seeking shelter begins the displacement process in the 1950s. Eventually there is a makeshift temple and the grave is destroyed, again through the actions of ordinary residents of the area. With the construction of a formal temple by the Sanatan Dharam Sabha in the 1960s, new meanings and practices replace earlier histories, although the dome, a material remnant of that past, still remains. The project of displacement is complete only in the late 1980s with the official denial of the space's Muslim past and destruction of the dome to expand the temple complex. Without any deliberate project or intentional plan of Muslim erasure, Muslim historical space becomes Hindu religious space.

\section{Illegal presence: The case of Noor Masjid}

A third instance of material displacements in Jangpura-Bhogal involves a different historical moment: the millennial contexts of 'new India' in the era of economic liberalization. We see here, once again, a process of displacement unfolding over a period of time, where the outcome of Muslim displacement is linked to discourses and initiatives that are not apparently or immediately connected to an overt majoritarian project. Instead, the new ideal of "worldclass city-making' and the attendant counter-discourse of obstructive 'illegalities' that must be vanquished ${ }^{53}$ engineers the displacement of a Muslim religious space.

In 2006, the Jangpura Residents Welfare Association (JRWA) filed a Public Interest Litigation (PIL) for the removal of unauthorized structures and encroachments, including a mosque and slum settlement of migrant Muslims alongside the Barapulla nala (drain) in Jangpura-B, which, they argued, were in direct violation of the Master Plan regulations for the city. In response, the Delhi High Court ordered the clearance of the encroachments in 2006. While the slum was cleared, the mosque, Noor Masjid, was left standing.

Dissatisfied with the outcome, the JRWA revived the litigation in 2008, arguing for the immediate demolition of the mosque. In its order of 8 July 2008 the court stated that the removal of the jhuggis (slums) and the construction of a wall to prevent future encroachments were adequate responses. While agreeing to reconsider the JRWA's requests, the court felt it unnecessary to continue monitoring the situation and disposed of the petition. ${ }^{54}$ In October 2010 , the JRWA filed a contempt petition against the

${ }^{53}$ D. A. Ghertner, Rule by Aesthetics: World-Class City Making in Delhi (New York: Oxford University Press, 2015); Rana Dasgupta, Capital: A Portrait of Twenty-First Century Delhi (Delhi: Fourth Estate, 2014); Véronique D. N. Dupont, 'The Dream of Delhi as a Global City', International Journal of Urban and Regional Research 35, no. 3 (May 2011), pp. 533-554, https://doi.org/10.1111/j.14682427.2010.01027.x.

${ }^{54}$ Jangpura Residents Welfare Association vs. Lt. Governor of Delhi and ORS. W.P. (C) 9358/2006 (Delhi High Court, 2006); Anuj Bhuwania, Courting the People: Public Interest Litigation in Post-Emergency India (Cambridge: Cambridge University Press, 2017), p. 105; Laurent Gayer and 
relevant national body, the Delhi Development Authority (DDA), for its failure to fully carry out the High Court's orders. The DDA, under the Indian National Congress (INC), responded by demolishing the Noor Masjid three months later, on 12 January $2011 .^{55}$

A demolition in response to a PIL was not a new phenomenon in the life of the city. Delhi's growth in the post-colonial period was accompanied (and made possible) by 'planned illegalities'. Urban planning failures to address the housing needs of the urban poor culminated in the proliferation of makeshift slums and tenements on public land. ${ }^{56}$ The city's numerous slum settlements have periodically faced the ire of Delhi's planners and administrators through slum clearance drives, especially during the Emergency (1975-77) and the build-up to the 2010 Commonwealth Games, with violent, concerted attempts to 'beautify' the city at the cost of the urban poor. ${ }^{57}$ In millennial Delhi, the efforts were taken up by the new middle classes, an influential political constituency in the age of economic liberalization and mediatized politics. Empowered by the state and supported by the courts, initiatives of 'bourgeois environmentalism ${ }^{158}$ used the discourse of 'illegality' to target habitations or means of livelihood for the urban poor, that is, hawkers and slums. ${ }^{59}$ Since the early years of the twenty-first century, PILs have been weaponized to cleanse the city's public spaces of undesirable elements, guided by ideals of urban order and a 'world-class' city aesthetic. ${ }^{60}$ Claims about 'illegal

Chakraverti Mahajan, 'Delhi's Noor Masjid: Tales of a Martyred Mosque', Economic and Political Weekly 46, no. 10 (2011), pp. 12-15.

55 'DDA Razes “Illegal” Masjid, Jangpura Erupts', Indian Express, 13 January 2011, http://archive. indianexpress.com/news/dda-razes--illegal--masjid-jangpura-erupts/736703/, [accessed 29 November 2021].

${ }^{56}$ As Bhan argues, these 'illegalities' emerge not only from the very nature of the settlements but also their location vis-à-vis the spatial limits of the Master Plan. In this context, slums or jj clusters largely developed in areas that came within the boundaries of the Master Plan's intended urban development. See Bhan, 'Planned Illegalities: The Production of Housing in Delhi, 1947-2010', in In the Public's Interest, pp. 44-94.

${ }^{57}$ Led by master planner Jagmohan, the most notable among them were the Turkman Gate (1976) and Yamuna Pushta (2004) slum clearances. See Sushmita Pati, 'Jagmohan: The Master Planner and the "Rebuilding" of Delhi', Economic and Political Weekly 49, no. 36 (2014), pp. 48-54; Tarlo, Unsettling Memories; Véronique Dupont, 'Slum Demolitions in Delhi since the 1990s: An Appraisal', Economic and Political Weekly 43, no. 12 (2008), pp. 79-87; Housing and Land Rights Network, Planned Dispossession: Forced Evictions and the 2010 Commonwealth Games (New Delhi: Housing and Land Rights Network, 2011).

${ }^{58}$ Baviskar, Uncivil City, p. 35.

${ }^{59}$ A key factor in this was the Bhagidari scheme. See D. A. Ghertner, 'Gentrifying the State: Governing through Property', in Rule by Aesthetics, pp. 45-77. For a similar phenomenon outside Delhi, see Jonathan Shapiro Anjaria, 'Guardians of the Bourgeois City: Citizenship, Public Space, and Middle-Class Activism in Mumbai', City and Community 8, no. 4 (December 2009), pp. 391406, https://doi.org/10.1111/j.1540-6040.2009.01299.x.

${ }^{60}$ Ghertner, Rule by Aesthetics. It is ironic that PILs, introduced to allow vulnerable populations a quick recourse to justice following the excesses of the Emergency (1975-77), are now the very weapons used to divest them of rights to the city. See Bhan, 'Planned Development and/as Crisis: Evictions and the Politics of Governance in Contemporary Delhi', in In The Public's Interest, pp. 95-145. 
encroachments' on public land have been vital to this process, and their use in the context of the Jangpura-Bhogal demolition litigation was not unusual, nor was the DDA's acquiescence in the face of negative media coverage.

However, the difference here lay in the absence of a demolition order from the High Court. Inquiries by the Zakat Foundation of India, an NGO, revealed that the order instructing the DDA to demolish the Noor Masjid was issued by the Religious Committee of the Lieutenant Governor's (LG) office on 30 April 2010. ${ }^{61}$ As news about this emerged, there were large-scale protests by Muslims in Delhi, supported by local and national political and religious leaders. ${ }^{62}$ Opposition leaders also entered the fray and questioned the role of the INC-led state and central governments in the razing of the mosque. ${ }^{63}$

The Delhi Wakf Board staked claim to the land where the Noor Masjid had formerly stood, citing the revenue record of 1947-48 and a 1975 gazette notification showing the site as allotted graveyard land. However, the court did not consider this evidence adequate and ruled in favour of the municipal authority's ownership of the land. ${ }^{64}$ Even though the Wakf's claims were denied by the judiciary, the massive protests and political furore around the incident meant that the DDA had to allot an alternative piece of land for rebuilding Noor Masjid in July 2011, paid for by the Delhi Wakf Board. ${ }^{65}$ Much to the disdain of the JRWA, today the Noor Masjid is located behind the DDA park of Jangpura-B. ${ }^{66}$

${ }^{61}$ Seema Mustafa, 'LG, CM Ordered Mosque Demolition', The Sunday Guardian, 16 January 2011, http://www.sunday-guardian.com/investigation/lg-cm-ordered-mosque-demolition, [accessed 29 November 2021]; 'Jangpura Masjid-High Court Did Not Order Demolition', Zakat Foundation, 13 January 2011, http://www.zakatindia.org/jangpuramosque.html, [accessed 29 November 2021]. This religious committee was especially formulated to determine the status of thousands of unauthorized religious structures in the city. It also authorized the demolition of an illegal Jagannath temple in Pushp Vihar in South Delhi, razed on the same day as the Noor Masjid. 'Post-Demolition, Protests Resonate amid Prayers', Hindustan Times, 15 January 2011, https://www.hindustantimes.com/delhi/post-demolition-protests-resonate-amid-prayers/storyWkgNOa6CULHjum0e16AmtL.html, [accessed 29 November 2021].

${ }^{62}$ Shoaib Iqbal; Asif Mohammed Khan; the chief imam of the Jama Masjid in Delhi Imam Bukhari; and Jangpura Member of the Legislative Assembly (MLA) Tarwinder Singh Marwah. 'After Bulldozers, Come the Netas', Indian Express, 14 January 2011, http://archive.indianexpress. com/news/after-bulldozers-come-the-netas/737208/0, [accessed 30 November 2021].

${ }^{63}$ Ibid. 'SP Condemns Demolition of Mosque in Delhi', Outlook Magazine, 15 January 2011, https:// www.outlookindia.com/newswire/story/sp-condemns-demolition-of-mosque-in-delhi/708512, [accessed 29 November 2021].

64 'Jangpura Masjid', Zakat Foundation. This area of Jangpura-B was graveyard land for Muslims, Christians, and Balmikis in the colonial and post-colonial period. See DSA, CC, LSG, 1949, 1-36, 'Plan Showing the Aligarh Nizampur Bhogal area graveyard Jangpura'. Legally, the land would have belonged to the Wakf. However, graveyards are one the most contentious issues between the Wakf and the DDA. See Delhi Minorities Commission, Problems and Status of Muslim Graveyards in Delhi: A Report (New Delhi: Delhi Minorities Commission, 2017).

65 'DDA to Allot Land to Mosque 3 Months after Demolishing It', Hindustan Times, 29 April 2011, https://www.hindustantimes.com/delhi/dda-to-allot-land-to-mosque-3-months-after-demolishingit/story-YnjC84ntgyHOGOoACdP7NJ.html, [accessed 29 November 2021].

66 '[T] $]$ he writ petition at the court stated the area was earmarked as a park. How can a group of encroachers be rewarded by the government barely 100 metres from the present position?: 
Almost a decade later, the rebuilt Noor Masjid is tainted by a perception of its illegality, even though it is now a legally sanctioned structure on purchased land, established by and through a judicial order. The perceived illegality of Noor Masjid stemmed from its continued association in the public discourse with the now destroyed slum and departed slum populations. As a member of the JRWA told me, "It was not a Masjid, it was just a slum. ${ }^{167}$ The Religious Committee had also considered the case of the Balmiki temple situated close to the Noor Masjid but decided to allot an alternative plot rather than demolition, a decision that raised criticism from those protesting against the demolition of the mosque. ${ }^{68}$ Although it was also included in the JRWA petition, the JRWA did not pursue it and accepted the committee's decision. The orders issued by the religious committee and conversations with residents suggest its protection from being demolished was due to its use and location. Its presence outside the slum cluster and its meanings for a present propertied Balmiki community residing in Bhogal ensured its survival.

The mosque's origins in the practices and spaces of the un-propertied could not easily be disavowed in local public imagination. ${ }^{69}$ At the same time as this idea of the mosque's essential and foundational illegality linked it to the nowabsent slum, other discourses stressed the absence of a slum population that warranted the existence of a mosque. The urgent needs of Jangpura-B's residents for a community centre and religious spaces were juxtaposed against the 'unnecessary mosque', which no longer had a population to cater for once the Barapulla settlement cluster had been razed. 'Jangpura-B does not even have a single Muslim. ${ }^{70}$

This was accompanied by the trope of the 'Bangladeshi' that is often used against Bengali- speaking migrants in the city. ${ }^{71}$ As Gayer and Mahajan have shown, in harnessing this abstract imaginary of dangerous 'outsiders' with the potential to threaten urban social life, residents articulated fears about the unwanted people that the mosque was likely to attract since there was no local constituency for it any longer. A new idea was put forward and gained

'Jangpura RWA Objects to Plot Offer', Times of India, 21 March 2011, https://timesofindia.indiatimes. com/city/delhi/Jangpura-RWA-objects-to-plot-offer/articleshow/7757320.cms, [accessed

November 2021].

${ }^{67}$ Interview with JRWA member, 17 October 2018.

68 'Delhi Home Department Letter to DDA', 28 October 2009, http://www.zakatindia.org/pdf/ Jangpura\%20masjid\%20Delhi\%20Home\%20Dept\%20letter\%20to\%20DDA.pdf, [accessed 29 November 2021]; 'After Bulldozers, Come the Netas', Indian Express, 14 January 2011.

${ }^{69}$ Baviskar highlights how their identities as migrants and middle-class definitions of property are used against the urban poor to divest them of rights to the city. Baviskar, Uncivil City, pp. 49-50.

${ }^{70}$ Interview with JRWA member, 17 October 2018; 'Jangpura Wants Land for Temple, HC Seeks Status', Hindustan Times, 20 August 2012, https://www.hindustantimes.com/delhi/jangpura-wantsland-for-temple-hc-seeks-status/story-wVkOAf8X0TexD0Y2gmubFO.html, [accessed 21 November 2021]. 'Jangpura Residents to Finally Get a Community Centre', Hindustan Times, 15 July 2016, https://www.hindustantimes.com/delhi/jangpura-residents-to-finally-get-a-community-centre/ story-eLogkbtyw7fbpOQ226PPLP.html, [accessed 29 November 2021].

${ }^{71}$ For a wider discussion, see Sujata Ramachandran, “'Operation Pushback”: Sangh Parivar, State, Slums, and Surreptitious Bangladeshis in New Delhi', Economic and Political Weekly 38, no. 7 (2003), pp. 637-647. 
rapid popularity in local circles that Noor Masjid should be shifted out of the neighbourhood entirely and be moved to where the slum dwellers had been relocated, to where the Muslims were. ${ }^{72}$

Like the material dispossessions discussed earlier, Noor Masjid's material and symbolic displacement was a prolonged process. The JRWA and the court first drew on the Master Plan and imagined urban ideals to remove the 'encroaching' Muslim slum cluster. Second, the absence that resulted from displacing a population that utilized it, and its presence in a slum, delegitimized the mosque's existence, eventually leading to its demolition. Instead, the JRWA argued in favour of land utilization for the community and religious needs of present and propertied non-Muslim populations. Third, the perceived illegality of the new structure continues to taint its existence and relegate its presence to an elsewhere, outside the spatial imaginary of Jangpura-Bhogal. Without overt ideological efforts to deny a Muslim presence, these processes nonetheless displace Muslim religious space.

\section{Narrative displacements}

All the material displacements discussed thus far, from Chand Khan's dispossession to the demolition of Noor Masjid, have involved processes that, although protracted over years if not decades, are now completed. Material displacements of Muslim property and historical and religious spaces are processes that belong to a concluded past. This section looks at how these past processes continue to affect Jangpura-Bhogal's present through their narrative afterlives.

The material displacements of the past and the Muslim absences they produced lay the ground for narrative displacement in the present, where Muslims are erased from popular memories of the neighbourhood and do not feature in public discourses about Jangpura-Bhogal's remembered diversity. This diversity is reworked against the neighbourhood's most recent migrant population, Afghan Muslims, to place them outside the normative ideals of community.

\section{Diversity and absence}

Residents define Jangpura-Bhogal, at times poetically, as a heterogenous familial space through their use of abstract phrases like bhaichara (brotherhood) and mil baat ke rehna (living together). ${ }^{73}$ The varied communities that were originally settled in the area, the arrival of migrant populations during partition, the presence of diverse religious structures like the church, mosque, gurudwara (Sikh temple), and a diversity of temples in a single neighbourhood are all invoked to assert the idea of the neighbourhood as an intrinsically heterogeneous space: "Every community has its own spaces. ${ }^{74}$ However, such

\footnotetext{
${ }^{72}$ Gayer and Mahajan, 'Delhi's Noor Masjid'.

${ }^{73}$ Kadimi Daadu, the owner of the one of the oldest sweet shops of Bhogal, was literally poetic in describing the virtues of Bhogal and its diversity through his recitation entitled 'What is the life of Bhogal'. Interview, 18 August 2017.

${ }^{74}$ Interview with Suresh, 5 July 2017.
} 
descriptions and recollections of a diverse history rarely mention a Muslim presence in the past. Dormant memories of Muslims in the past have to be activated through pointed questions like 'And Muslims?', 'Someone said that Muslims used to live here?', which lead to a mention of graves found in the area, shops they owned, streets they lived on, and their 'peaceful yet unfortunate' departure in 1947. Yet these stories do not reveal much about individual lives, names, or the villages they came from. Chand Khan, mentioned by a single individual, ${ }^{75}$ is otherwise absent, like other Muslim names in public memory. In contrast, names and origin details of non-Muslim residents, be it original allottees or partition refugees, routinely come up in my research conversations. In one instance, my discussion with regular visitors to the Ravidas temple in Bhogal in 2018 informs of family origins of people sitting around us. 'I am a Judbaghiya (from Jor Bagh), He is a Kushakiya (from Kushak), He is from Madarsa.... ${ }^{76}$

Similarly, local narratives about Bhogal's settlement often list six or seven villages that were displaced and relocated in 1922, identifying these as the origins or sources of the neighbourhood: Aliganj, Jorbagh, Pilanji, Madarsa, Arab ki Sarai, Raisina, and Kushak. Ranjana Sengupta, Sohail Hashmi, and the archive inform us of the relocation of Khairpur, a Muslim village, to Jangpura, to make way for the Lady Willingdon Gardens (now Lodhi Gardens). ${ }^{77}$ However, of the 19 narratives collected, only one mentions Khairpur. The village is almost absent from public memory. ${ }^{78}$

The absence of Muslims in settlement narratives is mirrored and magnified in popular memories of neighbourhood history. Thus, at one level, I am routinely presented with a picture of Jangpura-Bhogal's communal harmony. I am proudly told that the Hindu nationalist Rashtriya Swayamsevak Sangh (RSS) and its political party the Jana Sangh (now the Bharatiya Janata Party (BJP)) were never politically successful in Bhogal due to the neighbourhood's diverse social demography and the deep camaraderie among residents, which has always existed. ${ }^{79}$ Bhogal mein nahin hua (it didn't happen in

\footnotetext{
${ }^{75}$ Interview with Kishan Lal, 28 November 2018.

${ }^{76} 31$ October 2018.

${ }^{77}$ Sengupta, Delhi Metropolitan, p. 121; personal communication, 8 May 2017; NAI, Home, Public, 51-114, 1949.

${ }^{78}$ That one instance is Mange Lal, a Bhogal nonagenarian, who informs of events and stories otherwise absent from public memory. Interview, 12 December 2018. Although stray references to Muslims from Jor Bagh village or Muslims predating the colonial settlement exist, they are outliers in the larger public narrative. Interview with Kishan Lal, 28 November 2018; Interview with Rakesh, 25 December 2018.

${ }^{79}$ The Jangpura constituency has been a bastion of proclaimed secular parties like the Congress (INC) and the Aam Aadmi Party (AAP). In 1977, Inder Mohan Sehgal from the Janata Party (which included the Jana Sangh among others) won in the Jangpura constituency. He later joined the newly formed BJP but lost the next election (1983) to Jag Parvesh Chandra from the INC. An important point to note is that the Janata Party won the 1977 elections by riding on a wave of anti-Congress sentiment among the electorate following the Emergency. For details, see Statistical Report on General Election 1977 to the Legislative Assembly of National Capital Territory of Delhi, 16 (New Delhi: Election Commission of India), https://eci.gov.in/files/file/3868-delhi-1977/, [accessed 29 November 2021]; Election Commission of India, Statistical Report on General Election
} 
Bhogal) is the response I often get to my inquiries about past instances of communal violence. Bhogal's public narrative of 1947 tells us that violence occurred in Delhi but not in Bhogal, qualified by phrases like shantipriya log (peaceful people) ${ }^{80}$ and shaadi bya mein aana jaana (participation in intimate family events). ${ }^{81}$ A slippage in memory by a resident, Mange Lal, momentarily sheds light on the pillaging of Muslim homes in 1947-bahut loot paat hui (a lot of looting happened) $-{ }^{82}$ but this is an outlier in an otherwise uniform narrative about neighbourhood harmony and peace. Ruptures, when recognized, are often attributed to 'outsiders' and elsewheres. ${ }^{83}$

At another level, this positive story of neighbourhood diversity and amity is marked by a conspicuous and telling absence of Muslims. Like the absence of Khairpur in narratives of origin locations for Jangpura-Bhogal, spatial memories of the neighbourhood do not automatically feature a Muslim presence. While mentioning the communities settled, visual and oral recollections often leave out Muslims. They highlight the problematic spatial segregation between lower and upper caste populations ${ }^{84}$ or a positive proliferation of micro-localities by mentioning groups still present today. ${ }^{85}$ Enquiries about Muslims are welcomed and do reveal their spatial location in the vicinity of the mosque, a past recovered through pointed questions like "Where did the Muslims live?'. Yet invariably, these enquiries accompany a discussion of their departure, the arrival of partition Sikh and Hindu refugees, and the efforts of the Indian state to settle them in vacant Muslim houses and new tenements. ${ }^{86}$

Residents do not acknowledge this erasure as these Muslim histories can be vaguely recalled through verbal cues and, therefore, technically are not forgotten. As a result, these diluted histories can seamlessly fit into the abstract narrative of the diverse space. Their efforts to substantiate narratives of the neighbourhood's enduring abstract harmonious past lead to particular examples of present-day populations in the neighbourhood, sometimes including partition Sikh and Hindus and often omitting Muslims. In this unsurprising slippage of memory, Muslims are not necessarily forgotten, but unremembered.

1983 to the Legislative Assembly of National Capital Territory of Delhi, 17 (New Delhi: Election Commission of India), https://eci.gov.in/files/file/3871-delhi-1983/, [accessed 29 November 2021].

${ }^{80}$ Interview with Jain Saab, 26 February 2019.

${ }^{81}$ Interview with DC, 11 August 2017.

${ }^{82}$ Interview with Mange Lal, 6 December 2018.

${ }^{83}$ Gujjars from nearby Sarai Kale Khan are blamed for the Bakr Eid violence in 1928. Violence and 'minor' looting during the 1984 anti-Sikh pogrom are attributed to Congress supporters from 'outside'. For details on communal violence in 1928 and 1984, see DSA, DC, 1927, file no. 45, Report to DC, 1 June 1928; People's Union for Democratic Rights (PUDR) and People's Union for Civil Liberties (PUCL), Who Are the Guilty? Report of a Joint Inquiry into the Causes and Impact of the Riots in Delhi from 31 October to 10 November 1984 (Delhi: PUDR and PUCL, 1984).

${ }^{84}$ Interview with Ashok, 4 July 2017; Interview with Mange Lal, 6 December 2018.

${ }^{85}$ Interview with Jain Saab, 26 February 2019; Interview with Amma, 12 May 2017.

${ }^{86}$ Interview with Kishan Lal, 28 November 2011. 
So the Harijans were settled by the British on one side, Balmikis were settled on another side, Sainis were settled on one side, Punjabis were settled one side, Sardars were settled on one side, Brahmins were settled on one side, Baniyas on one side. Meaning they did the allotment in this way that one caste, one community live in separate locations so that they do not fight. ${ }^{87}$

As this example shows, by mentioning post-partition Punjabi Hindu and Sikh refugees in the original allotments, a slippage in recollection unifies temporally distanced arrivals and replaces Muslim residents from the time of neighbourhood settlement with partition refugees from several decades later. The spatial reconfigurations that partition brought about, when the refugee populations moved into empty Muslim houses and new constructions along Church Road and Masjid Road, reshape popular history and memory as well, evacuating the Muslim presence before 1947 and anachronistically placing partition refugees at the founding moment of Jangpura-Bhogal, decades before partition was even an idea.

This evident dissonance between the archive and memory emerges through a selective historical reconstruction of the neighbourhood and its diverse past. ${ }^{88}$ While justifying a past amity through the elision of ruptures and references to heterogeneous peoples and spaces, narrative slippages erase memories of bodies now absent. This erasure, however, is not necessarily the result of a deliberate project of forgetting or demonizing the Muslim pasts of the neighbourhood. ${ }^{89}$ The physical departure of Muslims and the accompanying material displacements discussed earlier, quite naturally and logically lead to the forgetting of details, their lives, names, and origins. Khairpur, one of the villages, or perhaps even the main one, where Muslims came from, disappears from memory; Muslims are remembered in an abstract sense on verbal cues, and they are forgotten when the neighbourhood's historical diversity is invoked, replaced by the Hindu and Sikh refugees in remembrances of the heterogenous space.

We might say then, that the ideal of the heterogeneous community emerges not only through experiential histories, spatial proximity, elevating or suppressing particular histories, ${ }^{90}$ but also through an unremembering of histories of absent populations. As material traces of their presence are slowly erased, their histories are diluted and relegated to the distant margins of public

\footnotetext{
${ }^{87}$ Interview with Mr. Vashisht, 9 March 2019, emphasis added.

${ }^{88}$ Donner and de Neve, 'Space, Place and Globalisation: Revisiting the Urban Neighbourhood in India', in The Meaning of the Local, pp. 1-20; Mills, 'Boundaries of the Nation'; Massey, 'Places and Their Pasts'; Blokland, 'Celebrating Local Histories'.

${ }^{89}$ Taneja, Jinnealogy; Rajagopalan, 'Postsecular Urbanisms'.

${ }^{90}$ Monika Salzbrunn, 'The Place-Making of Communities in Urban Spaces: The Invention of the Village Saint-Louis Sainte-Marthe', in Between Imagined Communities of Practice: Participation, Territory and the Making of Heritage, (eds) Nicolas Adell, Regina F. Bendix, Chiara Bortolotto and Markus Tauschek (Goettingen: Goettingen University Press, 2015), pp. 185-199; Mills, 'Boundaries of the Nation'; Pandey, 'Constructing Community', in Remembering Partition, pp. 175-205; Blokland, 'Celebrating Local Histories'.
} 


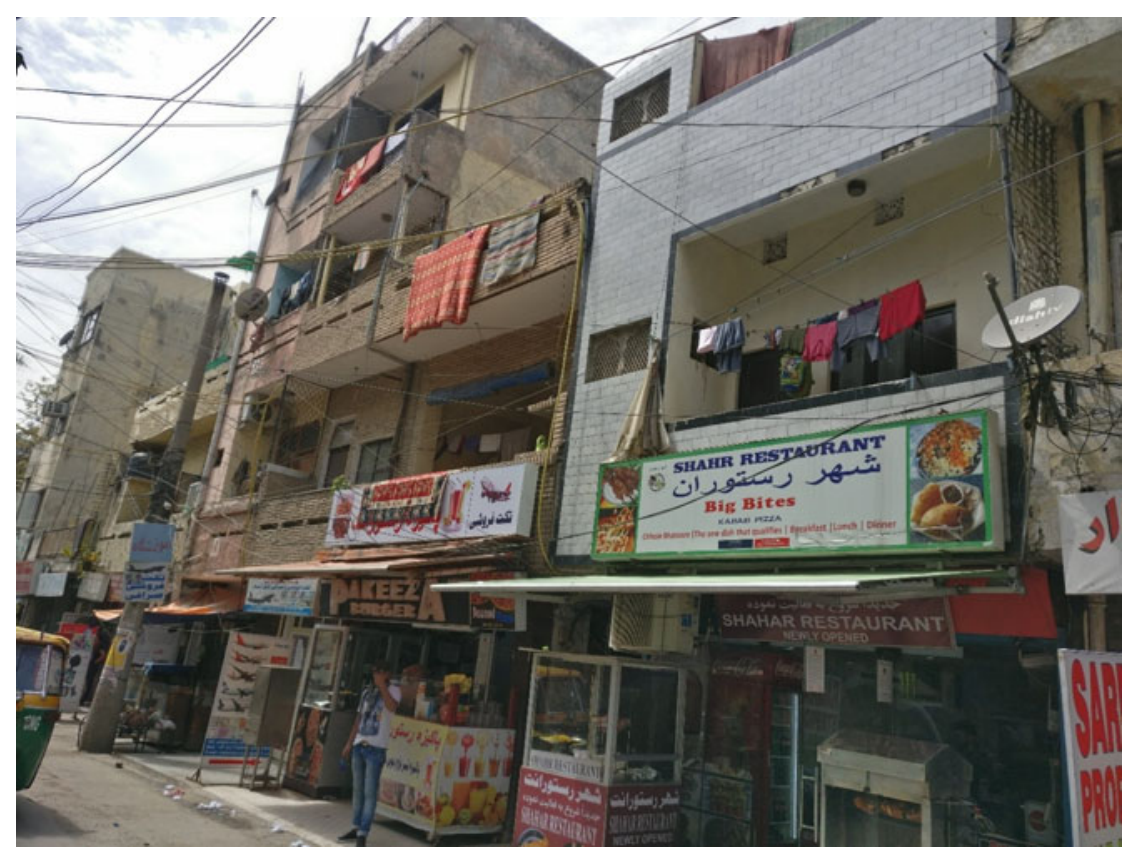

Figure 4. Afghan restaurants on Central Road, Bhogal. Source: The author.

memory, and their past is displaced from representations and recollections of the neighbourhood's diverse history.

\section{Present outsiders}

As of 2020 there are 207,334 officially documented 'people of concern' in India of whom 195,103 are registered refugees with the United Nations High Commissioner for Refugees (UNHCR). ${ }^{91}$ While most Afghan refugees $(15,761)^{92}$ in this population are Hindus or Sikhs residing in areas like West and North Delhi, ${ }^{93}$ Muslim refugees, students, and medical tourists choose to reside in areas of South and South-East Delhi such as Jangpura-Bhogal and neighbouring Lajpat Nagar. Concentrated in the areas around the Bhogal market, their imprint on the spatial landscape can easily be grasped on a walk down Central Road (see Figure 4). Afghan naanwais (breadmakers), restaurants,

${ }^{91}$ UNHCR, Operations, 'India', https://reporting.unhcr.org/india, [accessed 29 November 2021]. 'People of concern' include refugees, returnees, stateless people, the internally displaced, and asylum seekers.

92 UNHCR Refugee Data, android, v. 1.3., UNHCR'S Statistics Mobile App, https://www.unhcr.org/ refugee-statistics/, [accessed 29 November 2021].

${ }^{93}$ The Pashtun-led Taliban's violent, concerted efforts and claims to an Islamic Afghanistan led to the persecution of other ethnic and religious minorities, including Hindus, Sikhs, Christians, Hazaras, Tajiks, and Uzbeks. See Warsi, 'Being and Belonging in Delhi'; Ghosh, Identity and Marginality in India. 
grocery stores, travel agencies, and medical stores with boards in Dari catering to medical tourists fill the area, and the visible presence of Afghan bodies in public spaces, streets, and the Bhogal mosque is unmissable.

For most Afghan refugees who come to Bhogal, it is a temporary, transitory location while they seek to fulfil their ultimate intention of gaining asylum in the global North. But with the rate of visa acceptances declining over the years, most Afghan refugees have become resigned to an extended, and possibly permanent, stay in India. ${ }^{94}$

As mentioned earlier, Bhogal's proclaimed diversity elicits references to the different communities and religious sites in the neighbourhood, serving to illustrate the peaceful heterogeneity in the past and present. Yet, like the case of the 'missing Muslims' in recollections of the past, Afghans do not figure in claims of the neighbourhood's present diversity. When prompted with leading statements and pointed questions, 'and Afghans also came' responses present an abstracted, modular account of the neighbourhood presence of Afghans as just another link in the chain of urban arrivals. For beneficiaries of the booming rentier economy-the landlords and real estate agents of the areathe mention of Afghans is responded to with anodyne phrases like 'Bhogal is a bouquet'95 or 'whoever comes here settles in': $:{ }^{96}$ that is, the discussion of an Afghan presence generally serves as an occasion to assert the large-heartedness of the neighbourhood, how Bhogal has always been welcoming to people. ${ }^{97}$

These positive generalities quickly change as conversations progress and turn to specific details of everyday living in Jangpura-Bhogal. Invoking the logic and idiom of xenophobic global populist discourses on migration and refugees, residents tell me about the drastic decline (bedha garg) of a once convivial and familiar neighbourhood: 'We don't know who our neighbours are anymore. ${ }^{98}$ The laments about an unfamiliar neighbourhood are amplified by complaints about the high rents and prices, conduct of nefarious activities (dhanda), ${ }^{99}$ cultures of meat consumption, ${ }^{100}$ and the 'dirty' lifestyle that Afghans have brought to Jangpura-Bhogal. Questions are also raised about the legality of their visa documents and associated rights to own or rent property. This particular combination of tropes, that is, meat eating, illegal activities, and questionable documents, echoes a larger xenophobic discourse

${ }^{94}$ This is also reflected in conversations with Afghan shop owners and employees of the BOSCO centre, a partner of the UNHCR, who have been Bhogal denizens for many years.

${ }^{95}$ The suggestion here is that the diverse peoples constitute the 'flowers' of Bhogal. Interview with Jain Saab, 26 February 2019.

${ }^{96}$ Interview with Harpal, 17 January 2019.

${ }^{97}$ This also invites mentions of the brief stay of Irani and Iraqi Muslim populations following the outbreak of the Iran-Iraq War (1980-88).

${ }^{98}$ Interview with Dinkar, 18 July 2017; Interview with Amma, 12 May 2017.

${ }^{99}$ A colloquial term for drug trade and prostitution.

${ }^{100}$ Generally, meat consumption is not considered a problematic practice. For example, the consumption of chicken is widespread among Hindus and Sikhs in the city. However, at the same time, consumption of red meat (especially beef and pork) is also a trope to other groups like Muslims and Dalit slum dwellers in the city. For a discussion on meat politics and Muslim Othering, see Fachandi, 'Vibrant and Vegetarian Gujarat', in Pogrom in Gujarat, pp. 153-184. 
about groups like 'Nigerians' or Habshis, terms often used for African migrants in Delhi. ${ }^{101}$

These dystopian accounts of the Afghan presence unwittingly draw comparisons with remembered pasts of other kinds of migrant arrivals in the area. Like the contemporary Afghan refugees, partition refugees also lived through a turbulent and very difficult time but are seen to have risen to the challenge and succeeded in rebuilding their lives. ${ }^{102}$ Their arrival in the neighbourhood led to a positive sociocultural transformation and heightened economic enterprise, my informants tell me. In contrast to their self-reliant and entrepreneurial spirit, the locally prevalent narrative about the Afghan refugees emphasizes how they receive financial and legal support from the UNHCR, and strike collusive deals with local landlords, property dealers, and even the Indian government in order to lead a comfortable life at the expense of local residents.

The residence of Muslim Afghans in Jangpura-Bhogal and the presence elsewhere of their non-Muslim counterparts leads to an equation of the 'Afghan' with the 'Muslim Afghan'. While residents are aware of groups like Kabuli Sardars, ${ }^{103}$ discussions around Afghans invariably focus on the everyday practices and presence of Muslim Afghans residing in Jangpura-Bhogal. Thus, a uniform category of the 'Afghan (Muslim) Other' guides such utterances. The monetary capacities of medical tourists are superimposed on refugees. UN support for refugees is conflated with a universal assistance for all Afghans. Instances of drug trade and prostitution in the past colour perceptions of Afghan economic life. Lastly, the transitory nature of medical tourists and initial refugees shape the perception that all Afghan presence is temporary.

Material displacements of the past and their narrative afterlife replace Muslims with partition Sikh and Hindu refugees to redefine the idea of a heterogeneous community, which is reworked in the present moment. First, it utilizes an abstract history of different arrival populations to advocate an ever-present amicable diversity. Second, this narrative of the inclusive heterogeneous space is reworked to simultaneously define the neighbourhood community and exclude Afghans. It draws distinctions between a 'good' and a 'bad' diversity, between a positive diverse past and a dystopic present. The processes of a flourishing rentier economy and an international refugee regime, while facilitating their stay, simultaneously excludes them from the diverse present due to their difference and imagined transience. Although an Afghan presence

${ }^{101}$ Residents inform me that, unlike the Afghans, they have succeeded in driving Africans out of the area.

${ }^{102}$ This is similar to what Kaur has called the 'master narrative' of partition where individual and community efforts, irrespective of social status and state support, ensure the recovery of refugee lives. Kaur, Since 1947.

${ }^{103}$ In popular parlance, Kabuli Sardars (literally Sikhs from Kabul) refers to Afghan Sikhs. Interestingly, the neighbourhood's association with Afghan Sikhs through Hotel Kabli has largely been forgotten in public memory. Set up by Pritam Singh Kabli (i.e. from Kabul) as a residence for his employees in 1942, the bungalow became his residence after partition, and a hotel by the 1970s. Interview with Sukhbir Singh Kabli, 14 May 2017. See also Kai Friese, 'Afghans in India and One Hotel's Curious History: Bungalow in Bhogal', Bidoun no. 9 (2007). 
in Jangpura-Bhogal is visible and extensive, such narratives erase their presence by excluding them from the neighbourhood's positive heterogeneity.

\section{Conclusion}

This article has traced the constitutive role of displacement and city-making in a locality of Delhi: the Jangpura-Bhogal neighbourhood. I have shown how protracted processes of material displacement have contributed to the erasure of a Muslim historical presence from Jangpura-Bhogal. Tracing the afterlives of these material displacements, I have tracked how narrative discourses draw on these Muslim absences and the 'diverse space' to produce new sets of exclusions and practices of Othering in the present.

From 23-27 February 2020, North-East Delhi witnessed a concentrated episode of anti-Muslim violence that many have described as a systematic and organized 'pogrom'. Muslim residents were violently attacked, their places of work looted and destroyed, and religious and spiritual spaces desecrated. Official numbers state 53 deaths (including 15 Hindus), at least 250 injured, and an unknown number of missing persons. The build-up to the riots witnessed numerous inflammatory comments made by BJP leaders against protestors and Muslims in the city to polarize the electorate for the upcoming 2020 Delhi Legislative Assembly elections. Within hours of BJP leader Kapil Mishra's threat to remove the protestors in North-East Delhi by force, ${ }^{104}$ violence broke out on 23 February, marked by systematic and organized attacks by armed mobs in Muslim-majority areas and Muslim streets in non-Muslim areas. ${ }^{105}$

The immediate context was widespread public protest from mid-December 2019 that had taken place in the city and across the country against the passage of the Citizenship Amendment Act, and the related proposal to institute a National Population Register (the CAA-NPR combination). Introduced by the central BJP government, these measures were widely perceived to reconfigure constitutional citizenship along religious lines and block Muslim pathways to naturalized citizenship in particular. The protests that erupted were mostly confined to the Muslim areas of the city like Shaheen Bagh, Nizamuddin, and Jafrabad, among others, although they attracted substantial support from a wide cross-section of the population. While drawing praise and support from liberal circles, mainstream media coverage and social media discourse joined the government's loud condemnations that labelled these protests, and the neighbourhoods in which they were taking place, as anti-Indian and illegal.

The protest sites were eventually cleared by the government, and a short while later the concentrated violence of the February 'riots' enacted another

\footnotetext{
${ }^{104}$ Addressing a gathering of supporters in the presence of the police, he declared they would remain peaceful until US President Donald Trump's departure. If the police failed to clear the protest site by then, Mishra and his supporters would take matters into their hands, https://www.youtube.com/watch?v=M1RcLjP9068, [accessed 29 November 2021].

${ }^{105}$ Farah Naqvi, Sarojini N, Navsharan Singh and Naveen Chander, 'Let Us Heal Our Dilli: Eyewitness Report from North-East Delhi', 2020; Delhi Minorities Commission, Report of the Fact-Finding. The localities affected were Shiv Vihar, Khajuri Khas, Chand Bagh, Maujpur, Jafrabad, Gokulpuri, Ashok Nagar, Bhajanpura, Kadam Puri, Karawal Nagar, and Bhagirathi Vihar.
} 
clearing, displacing about 2,000 people from these neighbourhoods, confining them to relief camps and an uncertain future. ${ }^{106}$ The large-scale violence meted out on Muslim bodies was accompanied by methodical desecration, burning, and looting of Muslim religious and spiritual sites and properties.

Multiple reports have documented that these were no ordinary or spontaneous eruptions of popular violence, but were part of an institutionally organized plan, and that the police, local legislators (MLAs), and key figures from the central government (including parliamentary representatives and bureaucrats) were complicit in the events. The timing of the violence in the immediate aftermath of the CAA-NRC protests was not a coincidence, they argued: Muslims were being shown their place because they had risen up in protest. The attacks on Muslim-majority neighbourhoods showed how their already tenuous right to exist was contingent on their segregation and docility, the borders of which they had overstepped with the protests that had created a large, multi-religious opposition and inspired similar actions in many other neighbourhoods and other parts of the country as well. The threat that the protests posed-of a 'Muslim issue' sparking national solidarities and resistances-was successfully quelled through the February violence.

The idea of putting Muslims back in their place, confined to 'their' localities, reflects Delhi's particular urban experience. Although it has a relatively sparse history of communal riots, unlike other segregated cities in India, ${ }^{107}$ Delhi today is marked by a visibly segregated urban pattern and a growing intensity of anti-Muslim discourse in its public life. As documented by numerous scholars, Muslim spatial, political, and social marginalization have become part of the normative urban with Hindutva's rise since the 1980s. In Delhi's popular imagination today, Muslim spaces fetishized for the authentic and quaint 'Muslim experience' of narrow by-lanes, majestic mosques, and the gastronomical delights of 'Mughal food' are simultaneously spaces of suspicion. ${ }^{108}$ These are invariably understood to be exceptional spaces, outside the 'normal' or 'regular' neighbourhoods of Delhi.

These Muslim elsewheres of Delhi's public imagination are shaped and reinforced by the often invisible and extended processes of displacement that this article has explored. The violent attacks of February 2020 took place on the fertile ground of eventful as well as non-eventful histories of Muslim displacement. They were facilitated not only by the recent visible and violent histories of Muslim marginalization under the BJP regime, but also through the longer histories of non-overt, at times unintentional, processes of erasure,

\footnotetext{
${ }^{106}$ Alasdair Pal and Devkyot Ghoshal, 'Delhi's Displaced Scrape a Living after Deadly Riots', Reuters, 4 March 2020, https://www.reuters.com/article/us-india-citizenship-protests-displaceme-idUSKBN20R2FX, [accessed 29 November 2021]. The aftermath of the riots has witnessed the harassment and arrests of numerous Muslims, lawyers, and activists. See 'Delhi Riots', The Wire, https://thewire.in/tag/delhi-riots, [accessed 29 November 2021].

${ }^{107}$ Gayer, 'Safe and Sound: Searching for a "Good Environment" in Abul Fazl Enclave, Delhi', in Muslims in Indian Cities, pp. 213-236.

${ }^{108}$ Gayer and Jaffrelot, Muslims in Indian Cities; Kirmani, Questioning the Muslim Woman; Jamil, Accumulation by Segregation; Ajay Gandhi, 'Delicious Delhi: Nostalgia, Consumption and the old City', Identities 23, no. 3 (2016), pp. 345-361, https://doi.org/10.1080/1070289X.2015.1034130.
} 
displacement, and replacement of Muslims in the city's mainstream spaces in neighbourhoods like Jangpura-Bhogal.

Acknowledgements. This research would not have been possible without the constant support of Jangpura-Bhogal's residents. I am grateful to the two anonymous reviewers and editors of Modern Asian Studies for their insightful comments and suggestions. This article has benefited from Srirupa Roy's painstaking engagement with multiple drafts, Josefine Hoffmann, and Ayesha Kidwai's comments on earlier drafts, and conversations with Ashwin Subramanian, Nokmedemla Lemtur, and Vishal Singh Deo.

Competing interests. None.

Cite this article: Ahmad, Saeed. 2022. 'Muslim pasts and presents: Displacement and city-making in a Delhi neighbourhood'. Modern Asian Studies 56 (6), pp. 1872-1900. https://doi.org/10.1017/ S0026749X21000512 